\title{
Effects of Tiotropium and Salmeterol/Fluticasone Propionate on Airway Wall Thickness in Chronic Obstructive Pulmonary Disease
}

\author{
Makoto Hoshino $^{a}$ Junichi Ohtawab \\ Departments of a Respiratory Medicine and ${ }^{\mathrm{b}}$ Radiology, Atami Hospital, International University of Health and \\ Welfare, Atami, Japan
}

For editorial comment see p. 275

\section{Key Words}

Airway remodeling - Computed tomography · Chronic obstructive pulmonary disease · Salmeterol - Salmeterol/ fluticasone combination - Tiotropium

\begin{abstract}
Background: Triple inhalation therapy with tiotropium (Tio) and salmeterol/fluticasone propionate combination (SFC) is widely used in the treatment of chronic obstructive pulmonary disease (COPD). However, the effects of triple therapy on airway structural changes remain unknown. Objective: The aim of the study was to assess the effects of Tio, salmeterol (SM), SFC and Tio plus SFC on airway dimensions in COPD. Methods: A randomized, open-label, 4-way study ( $\mathrm{n}=$ 60) was conducted comparing 16-week treatment periods of Tio (18 $\mu$ g once daily), SM (50 $\mu$ g twice daily), SFC (50/250 $\mu \mathrm{g}$ twice daily) and Tio (18 $\mu \mathrm{g}$ once daily) plus SFC (50/250 $\mu \mathrm{g}$ twice daily). Airway dimensions were assessed by a validated CT technique, and airway wall area (WA) corrected for body surface area (BSA), percentage WA (WA\%), wall thickness/ $\sqrt{ } B S A$ and luminal area (Ai)/BSA at the right apical segmental bronchus were measured. Pulmonary function and the St. George's Respiratory Questionnaire (SGRQ) were evaluated. Results: Tio plus SFC resulted in a significant decrease in WA corrected for BSA and WA\% compared with Tio, SM and SFC ( $p<0.05$ for all). The changes in WA\% and $\mathrm{Ai} /$ $B S A$ were significantly correlated with changes in forced ex-
\end{abstract}

\section{KARGER}

E-Mail karger@karger.com

www.karger.com/res piratory volume in $1 \mathrm{~s}(\mathrm{r}=-0.86, \mathrm{p}<0.001$, and $\mathrm{r}=0.48, \mathrm{p}<$ 0.05 , respectively). There were more significant improvements in SGRQ scores after treatment with triple therapy than after the 3 other treatments. Conclusions: Tio plus SFC therapy is more effective than Tio, SM and SFC for reducing airway wall thickness in COPD.

Copyright $\odot 2013$ S. Karger AG, Basel

\section{Introduction}

According to the Global Initiative for Chronic Obstructive Lung Disease [1], inhaled bronchodilators, including long-acting $\beta_{2}$-agonists (LABAs) and long-acting muscarinic antagonists, are central to the symptomatic management of chronic obstructive pulmonary disease (COPD). These therapies, used alone or in combination, improve lung function and quality of life (QoL), prevent exacerbations and reduce hospitalization [2-8]. Based on the current COPD guideline [1], inhaled corticosteroid (ICS) therapy is reserved for patients with forced expiratory volume in $1 \mathrm{~s}\left(\mathrm{FEV}_{1}\right)<50 \%$ predicted who are experiencing 2 or more exacerbations per year requiring treatment.

The general consensus as reported in all international guidelines is that ICS are effective in reducing the number and severity of acute exacerbations of COPD [9]. The combination of LABAs and ICS improves lung function

Makoto Hoshino, MD, $\mathrm{PhD}$

Department of Respiratory Medicine, Atami Hospital International University of Health and Welfare

13-1 Higashikaigan-cho, Atami, Shizuoka 413-0012 (Japan)

E-Mail hoshino@iuhw.ac.jp 
and symptoms and reduces annual exacerbations compared with monotherapy alone [10-12]. Triple combination therapy with anticholinergics, ICS and LABA is widely used in clinical practice. This treatment approach is of interest because the goal of COPD management is to achieve optimal control, and with different mechanisms of action, there is reasonably good evidence to show that use of the 3 drugs in combination provides clinical benefits [13-15]. Treatment with the long-acting anticholinergic tiotropium (Tio) and salmeterol/fluticasone propionate combination (SFC) is therefore an attractive alternative for patients with more severe disease.

High-resolution computed tomography (CT) has been used to evaluate structural changes in the airways $[16,17]$ and lung parenchyma in COPD patients [18-20]. Crosssectional studies have shown that CT indices that quantify airway wall thickening and emphysema are correlated with pulmonary function measurements $[16,17,21,22]$. The combination of Tio plus SFC has been shown to be more effective than either treatment alone in terms of improving pulmonary function [13-15]. However, there is little evidence that Tio plus SFC affects airway dimensions in COPD patients.

The aim of the present study was to evaluate the effects of the Tio plus SFC combination, Tio alone, salmeterol (SM) alone and SFC on airway wall thickness and lumen area. Pulmonary function tests were also performed, and health-related QoL was assessed.

\section{Subjects and Methods}

\section{Subjects}

The subjects were patients $>40$ years of age with a diagnosis of COPD, a cigarette smoking history $>10$ pack-years, a postbronchodilator $\mathrm{FEV}_{1}<70 \%$ of the predicted value and ratio of $\mathrm{FEV}_{1}$ to forced vital capacity $(\mathrm{FVC})<0.70$. Exclusion criteria included a current diagnosis of asthma, a clinically significant medical disorder (other than COPD), supplemental use of oxygen for exertion or current use of some respiratory medications (including ICS, LABAs, Tio, theophylline or systemic corticosteroids). The subjects were either newly diagnosed COPD patients or entered a 2-week washout period at the start of which they discontinued the use of any current COPD medications. Concurrent use of salbutamol was permitted when necessary to relieve symptoms. All patients gave their written, informed consent, and the study protocol was approved by the hospital's ethics committee.

\section{Study Design}

This was a randomized, open-label, 4-way, clinical trial, with subjects allocated to receive treatment with one of the following: Tio $18 \mu \mathrm{g}$ once daily by Handihaler (Boehringer Ingelheim Pharma, Ingelheim, Germany); SM $50 \mu \mathrm{g}$ twice daily by Serevent (GlaxoSmithKline, London, UK); SFC 50/250 $\mu \mathrm{g}$ twice daily by
Adair (GlaxoSmithKline), or Tio $18 \mu$ g once daily plus SFC 50/250 $\mu \mathrm{g}$ twice daily. After a 2 -week run-in period, the subjects were randomized to one of the treatment groups; randomization was performed using a computer-generated list of random numbers. The treatment duration was 16 weeks, with clinical visits in weeks 4,8 , 12 and 16. Pulmonary function, CT and assessment of health-related QoL were carried out at screening and in week 16. At the final visit, we confirmed that the participants had last inhaled bronchodilators about $2 \mathrm{~h}$ previously and repeated lung function tests and CT. Adherence to the medication protocol was checked by the amount of medication remaining at each visit. Safety and adverse events were tracked through the study by checking laboratory test results and physical examinations performed at the final visit.

\section{Outcome Measurement}

The primary endpoint was the effect of treatment on airway dimensions, as assessed by CT scans. The secondary outcome measures were the mean change in pulmonary function and QoL parameters from baseline to week 16 .

\section{CT Measurement}

All subjects were scanned with a 64-detector CT scanner (Aquilion-64, Toshiba Medical, Tokyo, Japan) at full inspiration. Scans were obtained at $120 \mathrm{kV}, 200 \mathrm{~mA}$, slice thickness $1 \mathrm{~mm}$. Images were reconstructed with a bone algorithm at a slice thickness of $1 \mathrm{~mm}$ and an interval of $0.5 \mathrm{~mm}$. Images were stored in the Digital Imaging and Communications in Medicine format. After loading the Digital Imaging and Communications in Medicine images with a window width of $1,600 \mathrm{HU}$ and a window level of -600 $\mathrm{HU}$, cross-sectional images of the right upper lobe apical segmental bronchus (RB1) were selected. The RB1 was chosen because its long axis is generally perpendicular to the axial imaging plane, and prior studies have shown that measurements taken at this site correlate with lung function [16]. From the central point of the lumen, rays fanning out over $360^{\circ}$ were examined to determine airway walls along the rays using the full width at half-maximum principle [23]. The following airway parameters were then computed automatically by the program: luminal area $(\mathrm{Ai})$, total area of the airway (Ao), wall area $(\mathrm{WA}=\mathrm{Ao}-\mathrm{Ai})$, percentage $\mathrm{WA}(\mathrm{WA} \%=\mathrm{WA} /$ Ao/100) and absolute wall thickness (T). Because airway size may be affected by body size, Ai, WA and T were normalized to body surface area (BSA). To assess changes in lung volume, the crosssectional area of the lung was measured before and after treatment by tracing the outer perimeter of the lung parenchyma on the same slice that was used for measurement of airway dimensions [24].

\section{Reproducibility of Airway Dimensions}

Airway dimensions were measured by one observer (J.O.) in a blinded fashion. Intraobserver error was tested with an observer measuring Ai and WA\% in 10 randomly selected subjects 2 times. Intraobserver reproducibility was assessed by plotting the difference between the two measurements against the average value of the two. For each plot, the mean difference did not appreciably deviate from zero, and the limits of agreement were small [23, 25, 26].

\section{Pulmonary Function}

Pulmonary function testing was performed with a Fudak-77 (Fukuda Elect, Tokyo, Japan). FVC, $\mathrm{FEV}_{1}, \mathrm{FEV}_{1} \%$ and inspiratory capacity (IC) were measured. Residual volume was measured us- 
Table 1. Patients' demographics and baseline characteristics

\begin{tabular}{|c|c|c|c|c|}
\hline & Tio & SM & SFC & Tio + SFC \\
\hline Patients, $\mathrm{n}$ & 15 & 14 & 16 & 15 \\
\hline Age, years & $73(5)$ & $72(11)$ & $67(8)$ & $73(7)$ \\
\hline Male/female, $\mathrm{n}$ & $14 / 1$ & $12 / 2$ & $13 / 3$ & $13 / 2$ \\
\hline Smoking, pack-years & $57.2(35.5)$ & $60.1(57.2)$ & $66.0(49.5)$ & $47.1(37.7)$ \\
\hline $\mathrm{BSA}, \mathrm{m}^{2}$ & $1.57(0.12)$ & $1.59(0.17)$ & $1.55(0.14)$ & $1.56(0.19)$ \\
\hline $\mathrm{FEV}_{1}, 1$ & $1.29(0.61)$ & $1.53(0.83)$ & $1.25(0.38)$ & $1.38(0.65)$ \\
\hline $\mathrm{FEV}_{1} / \mathrm{FVC}, \%$ & $50.9(10.3)$ & $52.5(12.6)$ & $56.8(7.7)$ & $54.5(11.4)$ \\
\hline IC, 1 & $1.81(0.69)$ & $1.76(0.56)$ & $1.60(0.54)$ & $1.63(0.44)$ \\
\hline FRC, 1 & $4.10(0.44)$ & $3.82(0.56)$ & $3.97(0.59)$ & $3.56(0.77)$ \\
\hline $\mathrm{RV} / \mathrm{TLC}, \%$ & $49.5(16)$ & $51.5(13.9)$ & $50.9(6.7)$ & $51.4(12.1)$ \\
\hline $\mathrm{D}_{\mathrm{L}} \mathrm{CO} / \mathrm{V}_{\mathrm{A}}, \mathrm{ml} / \mathrm{min} / \mathrm{mm} \mathrm{Hg} / \mathrm{l}$ & $2.24(0.71)$ & $2.57(0.89)$ & $2.15(1.09)$ & $2.64(0.74)$ \\
\hline $\mathrm{Ai} / \mathrm{BSA}, \mathrm{mm}^{2} / \mathrm{m}^{2}$ & $8.2(5.9-10.2)$ & $9.5(6.1-11.7)$ & $8.8(6.2-10.9)$ & $7.9(6.7-8.4)$ \\
\hline \multicolumn{5}{|l|}{ SGRQ score } \\
\hline Symptoms & $43.1(17)$ & $45.6(17.9)$ & $51.4(23)$ & $50.1(19.9)$ \\
\hline Activity & $61.1(23.3)$ & $46.3(27.2)$ & $55.6(15.8)$ & $56.9(18)$ \\
\hline Impact & $35.5(21.9)$ & $27.5(20.6)$ & $35.5(12.4)$ & $33.5(17.7)$ \\
\hline Total & $43.1(19.9)$ & $36.2(19.2)$ & $44.8(13.4)$ & $42.2(16.3)$ \\
\hline
\end{tabular}

Data are presented as means $(\mathrm{SD})$ or medians (interquartile range). FRC $=$ Functional residual capacity; $\mathrm{RV}=$ residual volume; TLC $=$ total lung capacity; $\mathrm{D}_{\mathrm{L}} \mathrm{CO} / \mathrm{V}_{\mathrm{A}}=$ carbon monoxide transfer factor.

ing the helium dilution method, and functional residual capacity, total lung capacity, carbon monoxide transfer factor and alveolar volume were measured by the single-breath method.

Quality of Life

Health-related QoL was assessed using the St. George's Respiratory Questionnaire (SGRQ) for patients with COPD, and subscores of symptoms, activity and impact, as well as the total SGRQ score, were calculated [27].

\section{Statistical Analysis}

Sample size was calculated to give sufficient power to reject a two-sided test of the null hypothesis that there is no treatment difference among each treatment regimen with respect to airway dimensions as the primary outcome variable (significance set at $0.05)$. A conservative sample size of 17 subjects per group was chosen, with the aim of having 14 subjects who completed the study. This conservative sample size also ensured appropriate power (estimated, $78.2 \%$ ) to test the effects of treatment on airway dimensions. Values are presented as means (SD) or medians (interquartile ranges). Comparisons of quantitative variables were performed by nonparametric analysis, using the Mann-Whitney and Kruskall-Wallis tests for unrelated samples. The differences between the results at endpoint in terms of the changes from baseline were carried out using Wilcoxon's test for related samples. Compari- sons between two groups were performed using unpaired t tests. Comparisons of multiple groups were performed using analysis of variance with the Bonferroni correction. Relationships between parameters were assessed using Pearson correlation coefficients. A $\mathrm{p}$ value $<0.05$ was considered significant. All data were analyzed using StatView software (SAS Institute, Cary, N.C., USA).

\section{Results}

Sixty-eight screened patients were randomized; 8 of them discontinued the trial prematurely. Therefore, 60 patients were included in the efficacy analysis. The demographic and baseline characteristics of the patients are shown in table 1. Fifteen patients were treated with Tio, 14 with SM, 16 with SFC and 15 with Tio plus SFC. Demographic details, smoking history, baseline lung function, CT measurements and health-related QoL were matched among the treatment groups (table 1). Self-reported adherence to study medications was $>95 \%$ in each treatment group. 
Table 2. Airway dimensions and lung area in COPD patients before and after treatment with Tio, SM, SFC or Tio plus SFC

\begin{tabular}{|c|c|c|c|c|c|c|c|c|}
\hline & \multicolumn{2}{|l|}{ Tio } & \multicolumn{2}{|l|}{ SM } & \multicolumn{2}{|l|}{ SFC } & \multicolumn{2}{|l|}{ Tio + SFC } \\
\hline & before & after & before & after & before & after & before & after \\
\hline Ao, $\mathrm{mm}^{2}$ & $\begin{array}{l}31.5 \\
(23.9-44.3)\end{array}$ & $\begin{array}{l}33.1 \\
(22.2-49.2)\end{array}$ & $\begin{array}{l}30.5 \\
(19-37)\end{array}$ & $\begin{array}{l}28.9 \\
(19.8-36.5)\end{array}$ & $\begin{array}{l}28.9 \\
(20.6-39.5)\end{array}$ & $\begin{array}{l}29.5 \\
(21.4-35.7)\end{array}$ & $\begin{array}{l}29.2 \\
(25.2-34.9)\end{array}$ & $\begin{array}{l}29.1 \\
(22.7-35.6)\end{array}$ \\
\hline $\mathrm{Ai}, \mathrm{mm}^{2}$ & $\begin{array}{l}9.8 \\
(4.9-14.3)\end{array}$ & $\begin{array}{l}10.1 \\
(4.6-16.9)\end{array}$ & $\begin{array}{l}10.2 \\
(4.4-15.9)\end{array}$ & $\begin{array}{l}10.6 \\
(5.4-15.8)\end{array}$ & $\begin{array}{l}8.5 \\
(4.5-13)\end{array}$ & $\begin{array}{l}9.2 \\
(6.8-12.8)\end{array}$ & $\begin{array}{l}8.5 \\
(5.1-11.7)\end{array}$ & $\begin{array}{l}10.2 \\
(6.3-13.9)^{* *}\end{array}$ \\
\hline $\mathrm{T}, \mathrm{mm}$ & $\begin{array}{l}1.36 \\
(1.3-1.4)\end{array}$ & $\begin{array}{l}1.34 \\
(1.2-1.47)\end{array}$ & $\begin{array}{l}1.16 \\
(0.97-1.32)\end{array}$ & $\begin{array}{l}1.10 \\
(0.9-1.23)\end{array}$ & $\begin{array}{l}1.28 \\
(1.0-1.45)\end{array}$ & $\begin{array}{l}1.20 \\
(0.83-1.28)^{*}\end{array}$ & $\begin{array}{l}1.40 \\
(1.25-1.7)\end{array}$ & $\begin{array}{l}1.21 \\
(1.05-1.4)^{* *}\end{array}$ \\
\hline Lung area, $\mathrm{cm}^{2}$ & $\begin{array}{l}112.3 \\
(102-122.7)\end{array}$ & $\begin{array}{l}117.0 \\
(109.1-124.7)\end{array}$ & $\begin{array}{l}117.9 \\
(116.7-128)\end{array}$ & $\begin{array}{l}118.1 \\
(109.7-126.8)\end{array}$ & $\begin{array}{l}120.0 \\
(108.9-129.7)\end{array}$ & $\begin{array}{l}122.2 \\
(115.7-129.5)\end{array}$ & $\begin{array}{l}116.3 \\
(107.4-125.5)\end{array}$ & $\begin{array}{l}116.0 \\
(107-125.2)\end{array}$ \\
\hline
\end{tabular}

Data are presented as medians (interquartile range). ${ }^{*} \mathrm{p}<0.05,{ }^{* *} \mathrm{p}<0.01$ : compared with before treatment.

Table 3. Changes in measurements from baseline and patient efficacy variables after treatment with Tio, SM, SFC or Tio plus SFC

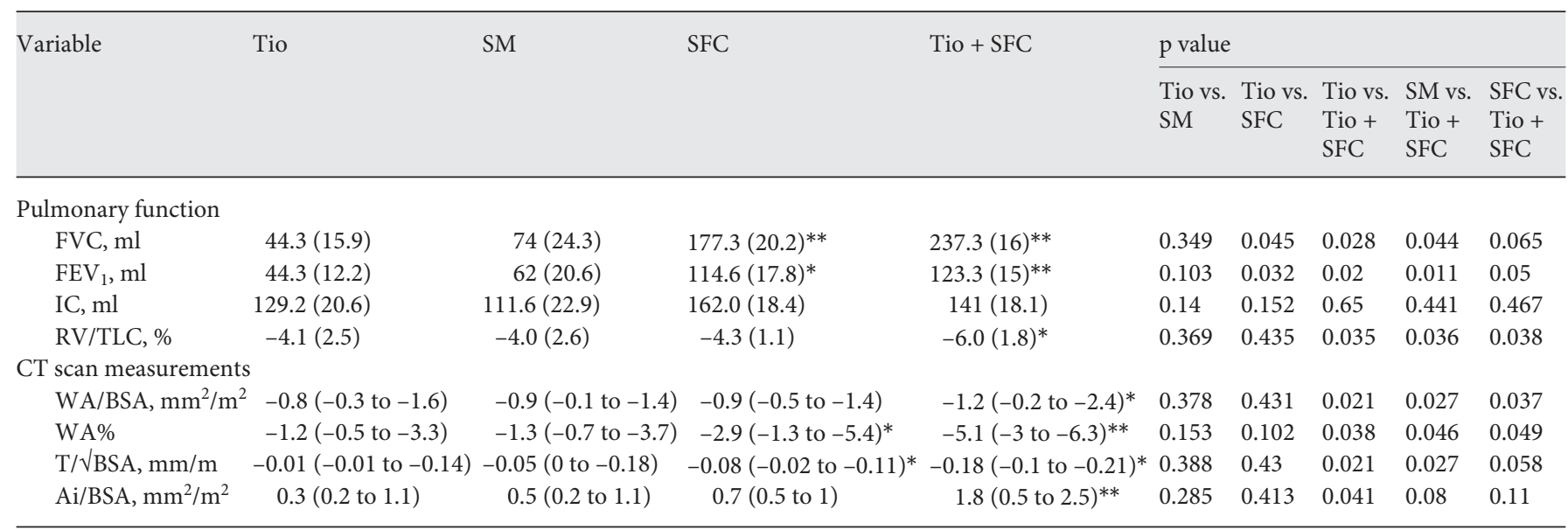

Data are presented as means (SD) or medians (interquartile range). ${ }^{*} \mathrm{p}<0.05,{ }^{* *} \mathrm{p}<0.01$ : compared with baseline, for within-group comparisons. $\mathrm{RV}=$ Residual volume; TLC = total lung capacity.

\section{Airway Measurements}

Original measurements of airway dimension and lung area before and after treatment are shown in table 2. The coefficients of variation for the measurements of $\mathrm{Ai}$ were $5.9 \pm 2.6 \%$ at baseline and $6.3 \pm 3.0 \%$ after treatment. The coefficients of variation of WA $\%$ were $4.7 \pm 2.8 \%$ at baseline and $5.4 \pm 3.2 \%$ after treatment. Tio plus SFC significantly increased $\mathrm{Ai}(\mathrm{p}<0.01)$ and significantly decreased $\mathrm{T}(\mathrm{p}<$ 0.01 ), and SFC alone also significantly decreased T ( $\mathrm{p}<$ 0.05 ) from baseline to end of treatment. No significant change was observed in Ao or lung area after any treatment. Tio plus SFC treatment significantly decreased WA corrected for $\mathrm{BSA}$, WA $\%$ and $\mathrm{T} / \sqrt{ } \mathrm{BSA}$ [median (interquartile range): $1.2 \mathrm{~mm}^{2} / \mathrm{m}^{2}(0.2-2.4), \mathrm{p}<0.05 ; 5.1 \%(3.0-6.3), \mathrm{p}<$
$0.01 ; 0.18 \mathrm{~mm} / \mathrm{m}(0.10-0.21), \mathrm{p}<0.05]$ and significantly increased Ai/BSA $\left[1.8 \mathrm{~mm}^{2} / \mathrm{m}^{2}(0.5-2.5), \mathrm{p}<0.01\right]$. The differences in WA corrected for BSA and WA\% were significantly greater than with Tio alone, SM alone and SFC ( $p<0.05$ for all). There was also a significant difference in T/ $\sqrt{ }$ BSA for Tio plus SFC compared with Tio alone and SM alone (table 3). SFC treatment significantly decreased WA $\%$ and $\mathrm{T} / \sqrt{ }$ BSA $[2.9 \%(1.3-5.4), \mathrm{p}<0.05 ; 0.08 \mathrm{~mm} / \mathrm{m}$ $(0.02-0.11), \mathrm{p}<0.05]$. However, these changes failed to show a statistically significant difference between Tio and SFC (table 3). There were no significant changes in airway dimensions in the patients receiving Tio or SM alone. The changes in WA\% before and after treatment with Tio, SM, SFC and Tio plus SFC are shown in figure 1. 


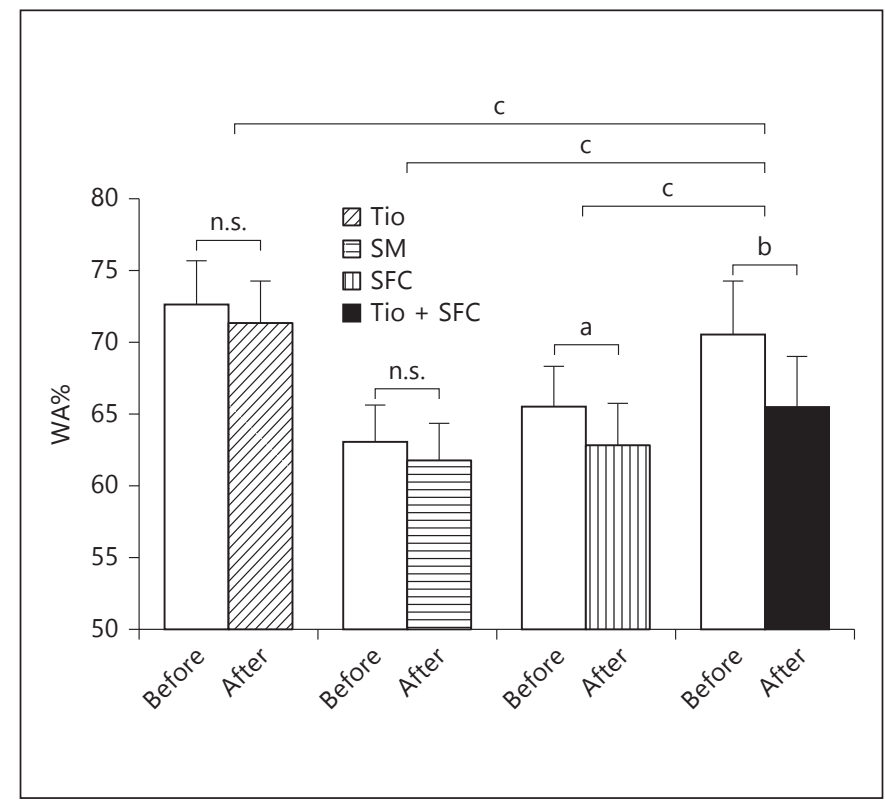

Fig. 1. Changes in WA\% before and after 16 weeks of treatment with Tio, SM, SFC or Tio plus SFC. Bars indicate medians (range). ${ }^{\mathrm{a}} \mathrm{p}<0.05,{ }^{\mathrm{b}} \mathrm{p}<0.001$ for within-group comparisons with baseline; ${ }^{c} \mathrm{p}<0.05$ for between-group comparisons of Tio plus SFC with Tio, SM and SFC.

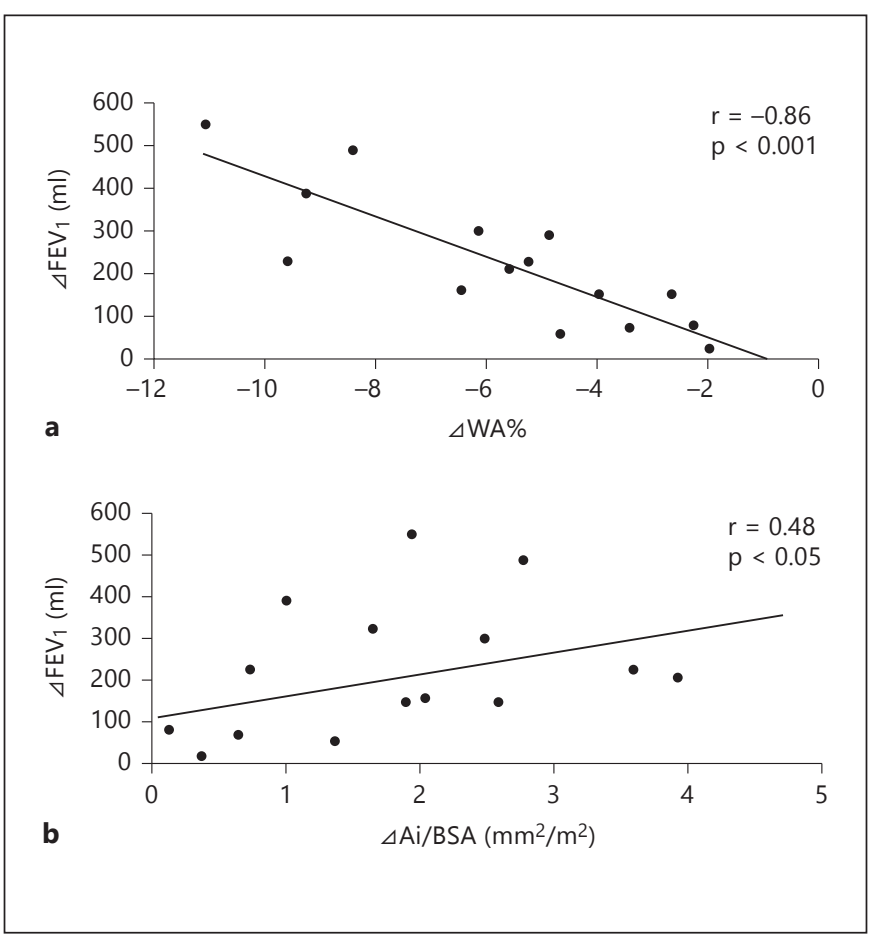

Fig. 2. Relationship between changes in $\mathrm{WA} \%$ and $\mathrm{FEV}_{1}$ (a) and changes in $\mathrm{Ai} / \mathrm{BSA}$ and $\mathrm{FEV}_{1}(\mathbf{b})$, before and after treatment with Tio plus SFC.

\section{Pulmonary Function}

Significant increases in FVC and $\mathrm{FEV}_{1}$, as well as decreases in residual volume/total lung capacity, at endpoint were observed following treatment with Tio plus SFC [mean (SD): $237.3 \mathrm{ml}(16), \mathrm{p}<0.01 ; 123.3 \mathrm{ml}$ (15), $\mathrm{p}<0.01 ; 6.0 \%$ (1.8), $\mathrm{p}<0.05]$. The difference between the improvements with Tio plus SFC and those with Tio alone, SM alone and SFC (except for FVC) were statistically significant ( $\mathrm{p}<0.05$ for all; table 3 ). There were also significant improvements in FVC and $\mathrm{FEV}_{1}$ with SFC compared with Tio alone $(\mathrm{p}<0.05)$. No treatment differences were found between the groups in terms of IC, functional residual capacity or carbon monoxide transfer factor. The increase in $\mathrm{FEV}_{1}$ after treatment with Tio and SFC was correlated with the decrease in WA\% $(r=-0.86$, $\mathrm{p}<0.001)$ and the increase in Ai/BSA $(\mathrm{r}=0.48, \mathrm{p}<0.05$; fig. 2).

\section{Quality of Life}

Over the study period, SGRQ scores improved in all 4 treatment groups. A decrease in the scores indicates improvement, with a change of 4 or more points indicating clinical improvement. Between-group comparisons indicated significantly greater improvements in SGRQ subscores of symptoms and activity in the Tio plus SFC group compared with the Tio, SM and SFC groups (fig. 3).

\section{Discussion}

This study showed that administration of Tio plus SFC resulted in a significant reduction in airway wall thickness in COPD patients compared with Tio, SM and SFC alone. In this study, Tio plus SFC provided greater improvement in $\mathrm{FEV}_{1}$ than Tio, SM or SFC. Particularly noteworthy is the finding that the changes in airway wall thickness and Ai were associated with improvement in airflow limitation. The superiority of triple inhalation therapy demonstrated by the range of airway dimensions and pulmonary function measurements translated into clinically important benefits in terms of symptom scores and activities, particularly compared with Tio and SM monotherapy and SFC.

SFC twice daily for 8 weeks significantly improved $\mathrm{FEV}_{1}$ and decreased lung hyperinflation compared with placebo [28]. A 2-month treatment with SM plus fluticasone propionate (FP) twice daily resulted in similar bronchodilation and reduction in SGRQ scores as did Tio once daily in patients with COPD [29]. SFC $(50 / 500 \mu \mathrm{g})$ plus 


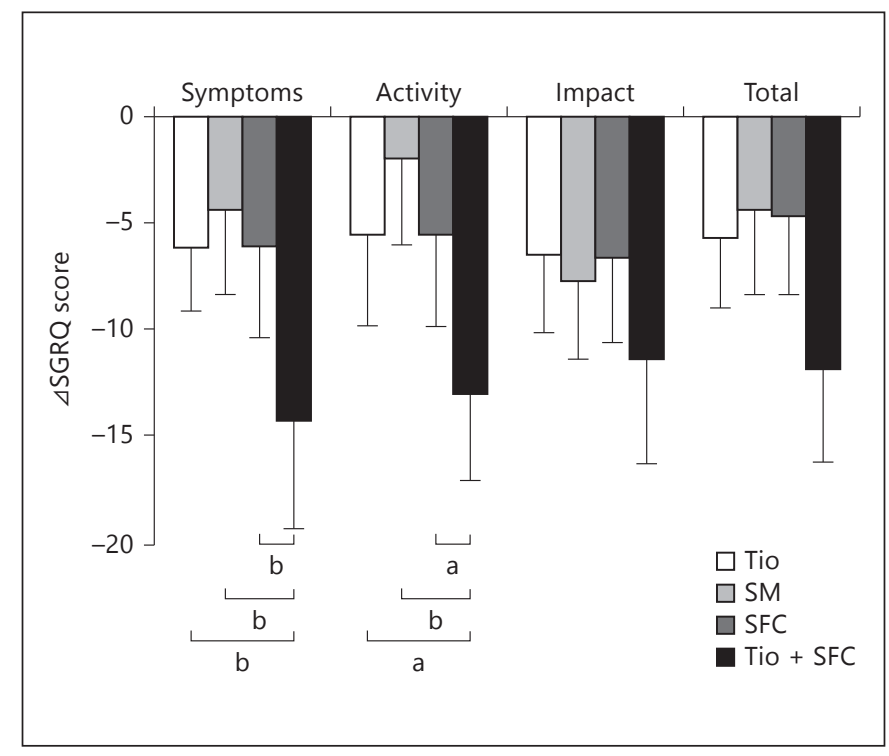

Fig. 3. Changes in SGRQ scores from baseline to after treatment with Tio, SM, SFC or Tio plus SFC. Bars indicate medians (range). ${ }^{\mathrm{a}} \mathrm{p}<0.05,{ }^{\mathrm{b}} \mathrm{p}<0.01$ for between-group comparisons of Tio plus SFC with Tio, SM and SFC.

Tio $(18 \mu \mathrm{g})$ for 14 days led to greater improvements in bronchodilation compared with SFC and Tio alone [15]. Therefore, treatment for 16 weeks is sufficient to evaluate the effect of each treatment on outcome measurements. COPD is an inflammatory disease of the airways characterized by progressive airflow limitation. The components of airway wall thickening that respond to treatment may include inflammatory processes. In COPD, neutrophils are increased in sputum and bronchoalveolar lavage fluid $[30,31]$, and patients with an accelerated decline in lung function have an increased sputum neutrophil differential count [32]. Three months of treatment with FP in COPD reduced the number of bronchial mast cells but not lymphocytes, neutrophils or macrophages [33]. The combination of SM and FP reduced sputum differential neutrophils and total eosinophils [34]. Another study demonstrated that SFC additionally reduced bronchial CD8+ cells and macrophages versus FP alone [35]. Structural changes in the airways include deposition of extracellular matrix, such as collagen, laminin and fibronection, in the subepithelial basement membrane. ICS and LABA combination therapy may also exert its effects not only by providing bronchodilation and functional antagonism, but also by reinforcing anti-inflammatory activity and attenuating airway wall thickness when compared with ICS therapy alone [36]. We recently reported that budesonide and formoterol combination therapy significantly reduced airway wall thickness and sputum eosinophilia compared to treatment with budesonide in asthma [37]. We speculate that SFC, as well as ICS plus LABA, i.e. budesonide and formoterol, attenuates inflammatory cell infiltration in the airways and is also able to inhibit remodeling.

M3-selective muscarinic antagonists have been shown to inhibit the release of chemoattractant for neutrophils from alveolar macrophages [38]. The upregulation of $\beta_{2}$ adrenergic receptors and anti-inflammatory effects by corticosteroids, which may account for the beneficial effect of corticosteroids in COPD therapy, are believed to include a reduction of muscarinic receptors in airway smooth muscle [39]. It has been demonstrated in guinea pigs that Tio reduces airway eosinophilia, as well as airway smooth muscle hypertrophy and goblet cell hyperplasia, upon repeated allergen exposure and leads to inhibition of several aspects of airway remodeling $[40,41]$.

$\mathrm{FEV}_{1}$ findings confirmed the superiority of Tio plus SFC therapy and agree with the findings of recent studies [13-15]. Singh et al. [15] demonstrated that triple therapy improves a range of pulmonary function measurements, including not only $\mathrm{FEV}_{1}$ and FVC but also IC. Although IC is a widely used index of pulmonary hyperinflation, the differences between Tio plus SFC and other monotherapy were always statistically nonsignificant in this study. The discrepancy in the results may be related to the small number of subjects assessed in the study to provide adequate statistical power for the observed treatment difference. Reduction of airway wall thickness is expressed as changes in WA, and bronchodilation is expressed as changes in Ai. These imaging data correlated with physiological data such as $\mathrm{FEV}_{1}$. The dimensions of the proximal airway (WA\% and $\mathrm{Ai}$ ) measured in CT images can predict the peripheral airway pathology [21] and have been found to correlate with airflow limitation [16] as well as clinical assessments such as respiratory symptoms [42]. The important role of small airway lesions has been well recognized in the airflow limitations in COPD [43]. Recently, it was reported that bronchodilation at the distal rather than the proximal airways determines functional improvement in airflow limitation in response to Tio in COPD [44]. If we had measured more peripheral sites of the airway dimensions through the development of CT technology, we may have provided some intriguing insights into the bronchodilator effect of Tio plus SFC.

It is also noteworthy that Tio plus SFC led to greater improvements in symptoms and QoL than the other 3 regimens. The results of the present study are consistent with previous observations $[13-15,45]$. Triple inhalation 
therapy is widely used in clinical practice for patients with COPD to optimize lung function, improve symptoms and reduce exacerbations.

There were some limitations to the present study. Firstly, this was an open-label design that did not include a placebo arm, as it could have raised ethical issues. The potential for bias to be introduced by patients and investigators in the assessment of outcomes should be considered when interpreting open-label data. Secondly, the present study had a low number of patients in each arm. Reducing airway wall thickness usually signifies improvement in airway remodeling, and controlling airway remodeling is a critical issue that has been left out in current COPD treatment. Due to the small numbers of participants in this study, many sources of interference that may have led to biases may have affected the results of treatment. Thirdly, only 1 bronchus (RB1) was assessed. However, a recent study suggested that airway measurements of RB1 correlated with other proximal airways, averaged in 19 segmental bronchi [46]. In our previous report, it was found that the relationship between Ai and pulmonary function was similar in 3 different lobes [23]. Fourthly, although CT images were obtained on 2 occasions while the patients held their breath at deep inspiration, the CT images might not have been obtained at precisely the same lung volume at each session, leading to some potential errors in comparison before and after therapy. However, such effects were unlikely because the lung area was not significantly different between the beginning and end of the study. Finally, there is increasing concern about medical exposure to radiation, and it must be remembered that CT does expose subjects to ionizing radiation. We think it may be possible to reduce the radiation dose in the evaluation of airway dimensions.

In conclusion, triple therapy with Tio plus SFC, compared with Tio, SM and SFC alone, provided greater reduction in airway wall thickness and improvement of lung function and QoL in COPD patients. This study demonstrates the benefits of triple inhalation therapy in the management of COPD.

\section{Acknowledgements}

The authors would like to thank the staff of the Division of Internal Medicine and the Department of Laboratory Medicine, Atami Hospital, International University of Health and Welfare.

\section{Financial Disclosure and Conflicts of Interest}

None of the authors has a financial relationship with a commercial entity that has an interest in the subject of the article.

\section{References}

1 Global Initiative for Chronic Obstructive Lung Disease: Global Strategy for the Diagnosis, Management, and Prevention of COPD. 2010. http://www.goldcopd.org/.

- 2 Rennard SI, Anderson W, ZuWallack R, Broughton J, Bailey W, Friedman M, Wisniewski M, Rickard K: Use of a long-acting inhaled beta2-adrenergic agonist, salmeterol xinafoate, in patients with chronic obstructive pulmonary disease. Am J Respir Crit Care Med 2001;163:1087-1092.

3 Mahler DA, Donohue JF, Barbee RA, Goldman MD, Gross NJ, Wisniewski ME, Yancey SW, Zakes BA, Rickard KA, Anderson WH: Efficacy of salmeterol xinafoate in the treatment of COPD. Chest 1999;115:957-965.

-4 Casaburi R, Mahler DA, Jones PW, Wanner A, San PG, ZuWallack RL, San PG, ZuWallack RL, Menjoge SS, Serby CW, Witek T Jr: A long-term evaluation of once-daily inhaled tiotropium in chronic obstructive pulmonary disease. Eur Respir J 2002;19:217-224.

5 Niewoehner DE, Rice K, Cote C, Paulson D, Cooper JA Jr, Korducki L, Cassino C, Kesten $S$ : Prevention of exacerbations of chronic obstructive pulmonary disease with tiotropium, a once-daily inhaled anticholinergic bronchodilator: a randomized trial. Ann Intern Med 2005;143:317-326.

-6 Tashkin DP, Celli B, Senn S, Burkhart D, Kesten S, Menjoge S, Decramer M: A 4-year trial of tiotropium in chronic obstructive pulmonary disease. N Engl J Med 2008;359:15431554.

7 van Noord JA, Aumann JL, Janssens E, Smeets JJ, Verhaert J, Disse B, Mueller A, Cornelissen PJ: Comparison of tiotropium once daily, formoterol twice daily and both combined once daily in patients with COPD. Eur Respir J 2005;26:214-222.

8 van Noord JA, Aumann JL, Janssens E, Smeets JJ, Zaagsma J, Mueller A, Cornelissen PJ: Combining tiotropium and salmeterol in COPD: effects on airflow obstruction and symptoms. Respir Med 2010;104:995-1004.

9 Global Initiative for Chronic Obstructive Lung Disease: Global Strategy for the Diagnosis, Management, and Prevention of COPD. 2007. http://www.goldcopd.com.

10 Calverley PM, Boonsawat W, Cseke Z, Zhong $\mathrm{N}$, Peterson S, Olsson H: Maintenance therapy with budesonide and formoterol in chron- ic obstructive pulmonary disease. Eur Respir J 2003;22:912-919.

11 Szafranski W, Cukier A, Ramirez A, Menga G, Sansores R, Nahabedian S, Peterson S, Olsson $\mathrm{H}$ : Efficacy and safety of budesonide/formoterol in the management of chronic obstructive pulmonary disease. Eur Respir J 2003;21:74-81.

12 Calverley PM, Anderson JA, Celli B, Ferguson GT, Jenkins C, Jones PW, Yates JC, Vestbo J: Salmeterol and fluticasone propionate and survival in chronic obstructive pulmonary disease. N Engl J Med 2007;356:775-789.

13 Aaron SD, Vandemheen KL, Fergusson D, Maltais F, Bourbeau J, Goldstein R, Balter M, O'Donnell D, McIvor A, Sharma S, Bishop G, Anthony J, Cowie R, Field S, Hirsch A, Hernandez P, Rivington R, Road J, Hoffstein V, Hodder R, Marciniuk D, McCormack D, Fox G, Cox G, Prins HB, Ford G, Bleskie D, Doucette S, Mayers I, Chapman K, Zamel N, FitzGerald M: Tiotropium in combination with placebo, salmeterol, or fluticasone-salmeterol for treatment of chronic obstructive pulmonary disease: a randomized trial. Ann Intern Med 2007;146:545-555. 
14 Cazzola M, Andò F, Santus P, Ruggeri P, Di Marco F, Sanduzzi A, D'Amato M: A pilot study to assess the effects of combining fluticasone propionate/salmeterol and tiotropium on the airflow obstruction of patients with severe-to-very severe COPD. Pulm Pharmacol Ther 2007;20:556-561.

- 15 Singh D, Brooks J, Hagan G, Cahn A, O'Connor BJ: Superiority of 'triple' therapy with salmeterol/fluticasone propionate and tiotropium bromide versus individual components in moderate to severe COPD. Thorax 2008;63:592-598.

-16 Nakano Y, Muro S, Sakai H, Hirai T, Chin K, Tsukino $\mathrm{M}$, Nishimura $\mathrm{K}$, Itoh $\mathrm{H}$, Paré PD, Hogg JC, Mishima M: Computed tomographic measurements of airway dimensions and emphysema in smokers. Correlation with lung function. Am J Respir Crit Care Med 2000;162:1102-1108.

17 Hasegawa M, Nasuhara Y, Onodera Y, Makita H, Nagai K, Fuke S, Ito Y, Betsuyaku T, Nishimura M: Airflow limitation and airway dimensions in chronic obstructive pulmonary disease. Am J Respir Crit Care Med 2006; 173:1309-1315.

18 Thurlbeck WM, Müller NL: Emphysema: definition, imaging, and quantification. Am J Roentgenol 1994;163:1017-1125.

19 Foster WL Jr, Pratt PC, Roggli VL, Godwin JD, Halvorsen RA Jr, Putman CE: Centrilobular emphysema: CT-pathologic correlation. Radiology 1986;159:27-232.

-20 Bergin C, Müller N, Nichols DM, Lillington G, Hogg JC, Mullen B, Grymaloski MR, Osborne S, Paré PD: The diagnosis of emphysema. A computed tomographic-pathologic correlation. Am Rev Respir Dis 1986;133:541-546.

-21 Nakano Y, Wong JC, de Jong PA, Buzatu L, Nagao T, Coxson HO, Elliott WM, Hogg JC, Paré PD: The prediction of small airway dimensions using computed tomography. Am J Respir Crit Care Med 2005;171:142-146.

$\checkmark 22$ Orlandi I, Moroni C, Camiciottoli G, Bartolucci M, Pistolesi M, Villari N, Mascalchi M: Chronic obstructive pulmonary disease: thinsection CT measurement of airway wall thickness and lung attenuation. Radiology 2005; 234:604-610.

23 Matsuoka S, Kurihara Y, Yagihashi K, Hoshino M, Nakajima Y: Airway dimensions on inspiratory and expiratory multisection $\mathrm{CT}$ in chronic obstructive pulmonary disease: correlation with airflow limitation. Radiology 2008;248:1042-1049.

-24 Okazawa M, Müller N, McNamara AE, Child S, Verburgt L, Paré PD: Human airway narrowing measured using high resolution computed tomography. Am J Respir Crit Care Med 1996;154:1557-1562.
5 Matsuoka S, Kurihara Y, Nakajima Y, Niimi $\mathrm{H}$, Ashida H, Kaneoya K: Serial change in airway lumen and wall thickness at thin-section CT in asymptomatic subjects. Radiology 2005;234:595-603.

26 Hoshino M, Matsuoka S, Handa H, Miyazawa $\mathrm{T}$, Yagihashi K: Correlation between airflow limitation and airway dimensions assessed by multidetector CT in asthma. Respir Med 2010;104:794-800.

27 Jones PW, Quirk FH, Baveystock CM, Littlejohns P: A self-complete measure for chronic airflow limitation: the St. George's Respiratory Questionnaire. Am Rev Respir Dis 1992; 145:1321-1327.

28 O’Donnell DE, Sciurba F, Celli B, Mahler DA, Webb KA, Kalberg CJ, Knobil K: Effect of fluticasone propionate/salmeterol on lung hyperinflation and exercise endurance in COPD. Chest 2006;130:647-656.

29 Kurashima K, Hara K, Yoneda K, Kanauchi T, Kagiyama N, Tokunaga D, Takayanagi N, Ubukata M, Sugita Y: Changes in lung function and health status in patients with COPD treated with tiotropium or salmeterol plus fluticasone. Respirology 2009;14:239-244.

30 Ronchi MC, Piragino C, Rosi E, Amendola M, Duranti R, Scano G: Role of sputum differential cell count in detecting airway inflammation in patients with chronic bronchial asthma or COPD. Thorax 1996;51:1000-1004.

31 Riise GC, Ahlstedt S, Larsson S, Enander I, Jones I, Larsson P, Andersson B: Bronchial inflammation in chronic bronchitis assessed by measurement of cell products in bronchial lavage fluid. Thorax 1995;50:360-365.

- 32 Stănescu D, Sanna A, Veriter C, Kostianev S, Calcagni PG, Fabbri LM, Maestrelli P: Airways obstruction, chronic expectoration, and rapid decline of $\mathrm{FEV}_{1}$ in smokers are associated with increased levels of sputum neutrophils. Thorax 1996;51:267-271.

33 Hattotuwa KL, Gizycki MJ, Ansari TW, Jeffery PK, Barnes NC: The effects of inhaled fluticasone on airway inflammation in chronic obstructive pulmonary disease: a doubleblind, placebo-controlled biopsy study. Am J Respir Crit Care Med 2002;165:1592-1596.

-34 Barnes NC, Qiu YS, Pavord ID, Parker D, Davis PA, Zhu J, Johnson M, Thomson NC, Jeffery PK: Antiinflammatory effects of salmeterol/fluticasone propionate in chronic obstructive lung disease. Am J Respir Crit Care Med 2006;173:736-743.

-35 Bourbeau J, Christodoulopoulos P, Maltais F, Yamauchi Y, Olivenstein R, Hamid Q: Effect of salmeterol/fluticasone propionate on airway inflammation in COPD: a randomised controlled trial. Thorax 2007;62:938-943.
36 Roth M, Johnson PR, Rüdiger JJ, King GG, Ge Q, Burgess JK, Anderson G, Tamm M, Black JL: Interaction between glucocorticoids and beta 2 agonists on bronchial airway smooth muscle cells through synchronised cellular signalling. Lancet 2002;360:1293-1299.

37 Hoshino M, Ohtwa J: Effects of budesonide/ formoterol combination versus budesonide on airway dimensions in asthma. Respirology 2012;17:639-646.

38 Sato E, Koyama S, Okubo Y, Kubo K, Sekiguchi M: Acetylcholine stimulates alveolar macrophages to release inflammatory cell chemotactic activity. Am J Physiol 1998;274:L970-L979.

39 Emala CW, Clancy J, Hirshman CA: Glucocorticoid treatment decreases muscarinic receptor expression in canine airway smooth muscle. Am J Physiol 1997;272:L745-L751.

40 Bos IS, Gosens R, Zuidhof AB, Schaafsma D, Halayko AJ, Meurs H, Halayko AJ, Meurs H, Zaagsma J: Inhibition of allergen-induced airway remodelling by tiotropium and budesonide: a comparison. Eur Respir J 2007; 30:653-661.

41 Gosens R, Bos IS, Zaagsma J, Meurs H: Protective effects of tiotropium bromide in the progression of airway smooth muscle remodeling. Am J Respir Crit Care Med 2005;171: 1096-1102.

42 Grydeland TB, Dirksen A, Coxson HO, Eagan TM, Thorsen E, Pillai SG, Sharma S, Eide GE, Gulsvik A, Bakke PS: Quantitative computed tomography measures of emphysema and airway wall thickness are related to respiratory symptoms. Am J Respir Crit Care Med 2010; 181:353-359.

43 Hogg JC, Chu F, Utokaparch S, Woods R, Elliott WM, Buzatu L, Cherniack RM, Rogers RM, Sciurba FC, Coxson HO, Paré PD: The nature of small-airway obstruction in chronic obstructive pulmonary disease. $\mathrm{N}$ Engl J Med 2004;350:2645-2653.

44 Hasegawa M, Makita H, Nasuhara Y, Odajima N, Nagai K, Ito Y, Betsuyaku T, Nishimura $\mathrm{M}$ : Relationship between improved airflow limitation and changes in airway calibre induced by inhaled anticholinergic agents in COPD. Thorax 2009;64:332-338.

45 Jung KS, Park HY, Park SY, Kim SK, Kim YK, Shim JJ, Moon HS, Lee KH, Yoo JH, Lee SD: Comparison of tiotropium plus fluticasone propionate/salmeterol with tiotropium in COPD: a randomized controlled study. Resp Med 2012;106:382-389.

46 Aysola RS, Hoffman EA, Gierada D, Wenzel S, Cook-Granroth J, Tarsi J, Zheng J, Schechtman KB, Ramkumar TP, Cochran R, Xueping E, Christie C, Newell J, Fain S, Altes TA, Castro M: Airway remodeling measured by multidetector $\mathrm{CT}$ is increased in severe asthma and correlates with pathology. Chest 2008;134:1183-1191. 